\title{
Environmental and Occupational Pollutants and Their Effects on Health among Brick Kiln Workers
}

\author{
Seshananda Sanjel' ${ }^{1}$, Steven M. Thygerson ${ }^{2 *}$, Sanjay N. Khanal ${ }^{1}$, Sunil Kumar Joshi ${ }^{3}$ \\ ${ }^{1}$ Department of Environmental Science and Engineering, Kathmandu University, Dhulikhel, Nepal \\ ${ }^{2}$ Department of Health Science, Brigham Young University, Provo, UT, USA \\ ${ }^{3}$ Department of Community Medicine, Kathmandu Medical College, Kathmandu, Nepal \\ Email: *steven.thygerson@byu.edu
}

How to cite this paper: Sanjel, S., Thygerson, S.M., Khanal, S.N. and Joshi, S.K. (2016) Environmental and Occupational Pollutants and Their Effects on Health among Brick Kiln Workers. Open Journal of Safety Science and Technology, 6, 81-98. http://dx.doi.org/10.4236/ojsst.2016.64008

Received: August 3, 2016

Accepted: December 4, 2016

Published: December 9, 2016

Copyright $\odot 2016$ by authors and Scientific Research Publishing Inc. This work is licensed under the Creative Commons Attribution International License (CC BY 4.0). http://creativecommons.org/licenses/by/4.0/

\begin{abstract}
The ever expanding traditional brick industry in Nepal is a labour intensive, low technology activity found in the Kathmandu Valley and Terai regions of Nepal. While environmental pollutants associated with brick making have been characterized, the effects of these pollutants on the workers themselves have received relatively little attention. This review attempts to summarize and interpret the available recent evidences characterizing the extent of exposure to risk factors and health problems of brick kiln workers.
\end{abstract}

\section{Keywords}

Brick Kiln Emission, Occupational Exposure, Respiratory Problems, Musculoskeletal Disorders

\section{Introduction}

It has been said that the study of brick making is the study of civilization because brick, made of mud and straw, has been used for thousands of years [1]. Brick production was started in Nepal from the very beginning and this is a part of art and architecture [2]. The brick industry is considered a small/cottage industry and there is only seasonal employment opportunity despite an enormous amount of investment [2]. In conjunction with the urbanization, brick industries are rapidly increasing and migrations of people into the city areas pressurize to produce more brick. As a result, more and more brick kilns are being built. At present, over 400,000 people are engaged in work in the brick industry in Nepal [2]. Coal, which is imported mainly from India, is used as a chief fuel for kilning the bricks in Nepal. There are five main brick firing technologies: 
Clamp Kiln, Movable Chimney Bull Trench Kiln (MCBTK), Fixed Chimney Bull Trench Kiln (FCBTK), Vertical Shaft Brick Kiln (VSBK) and Hoffman Kiln [3]. MCBTK constitutes $57 \%$ of the market share and the major prevalent technology in Nepal. FCBTK share of the brick kiln industry is $33 \%$, Clamp Kiln is $6.7 \%$, VSBK is $3.6 \%$ and Hoffman is $0.3 \%$ [3]. The government has recently banned the MCBTK since 2011 replacing with FCBTK.

Kathmandu valley has the bowl shape geographical structure which does not allow the pollutants to release outside the valley through wind pressure. Brick industries contribute as the second chief source of air pollution next to vehicle emission and road settlements [4]. One study found that the concentration of airborne particulate matter in the brick kiln regions is much higher during the brick making season compared to the off season [4].

Brick manufacturing plants are the most polluted workplaces in Nepal causing respiratory, gastrointestinal, reproductive, psychosocial and skin diseases [5]-[10]. Despite the enormous health problems among brick kiln workers, the existence of occupational safety and health services are negligible in Nepal [11]. Moreover, the studies on the occupational safety and health status are also very few [12]. This review examines the air pollution levels in Kathmandu valley and health effects of workers who engage in brick production activities. It provides insight to the various hazards associated with the brick kiln industry based on previous studies. The information contained herein can aid in the identification and implementation of interventions aimed at mitigating the known hazards.

\section{Methods}

The review attempts to summarize and interpret the available recent evidences of the extent of exposure to risk factors and health problems of brick kiln workers. Review of existing research work (e.g., published research articles, unpublished research works, organizational and corporate reports and theses) was carried out taking into consideration the types of environment and occupational pollutants and their effect on human health.

Computerized search of articles was completed using Science Citation Index, Pubmed, Medline and Google Scholar to assess must recent articles. Other relevant websites were also visited. Government policies, plans, reports were intensely reviewed. The I/NGO publications and reports were reviewed as well.

The following key words were used to search the electronic materials: brick kiln emission; dust pollution; gas pollution; sulphur pollution; nitrogen pollution; carbon monoxide pollution; heat pollution; noise pollution; respiratory problems; musculoskeletal disorders; ergonomics problems; and psychosocial problems.

\section{Brick Kiln Pollutants and Health}

All levels of enterprises across the globe, from small corporations to the national and international companies, have been concerned regarding the human, social and eco- 
nomic costs of work-related injuries and diseases [13]. To overcome such challenges, the cross-disciplinary area "Occupational Safety and Health (OSH)" has emerged for protecting wellbeing, health and safety of the employees [12]. However, in most developing countries, achieving the goal of fostering a safe work environment is severely hampered by particular problems such as high illiteracy rates, lack of awareness on safety and health and poor functioning or carelessness of the related authorities in implementing OSH policies actions [14]. Similarly, the creation of OSH in Nepal is still in its conceptual phase. The government of Nepal has imposed some OSH rules through its Labor Act of 1992. It has pointed out some concerns and prerequisites on working hours, physical infrastructural setup, yearly medical examination and provisions of safety measures in work [15]. Nevertheless, practical applications of these matters are in question.

The brick kiln industry, especially in developing countries like Nepal, have serious $\mathrm{OSH}$ concerns. Although brick manufacturing is a high risk industry, risky, escalating poverty and fewer possibilities of getting a job in the rural regions force the deprived people to join unsafe work like brick manufacturing. To cater to the need of housing expansion, brick kilns growth is exponential in most of the developing countries. In Nepal, brick kilns (especially, Bull's trench kilns) have tripled in a ten year period in the 1980s and 1990s from 102 in 1984 to 305 in 1993 [16]. It is a growing unorganized industrial sector. The most recent data published by the Ministry of Environment and Science and Technology (MoEST) estimated that there are almost 575 brick kilns operating in Nepal. A range of 15,000 to 50,000 bricks are produced each day [17].

The different types of brick kilns include: Fixed Chimney Bull's Trench Kiln (FC BTK), Movable Chimney Bull's Trench Kiln (MC BTK), Fixed Chimney Force Draught Bull's Trench Kiln (FC FD BTK), Fixed Chimney Natural Draught Bull's Trench Kiln (FC ND BTK), and Vertical Shaft Brick Kiln (VSBK) [18]. Across the developing world, brick making is still typically a manual process. In Nepal, the most common type of kilns used is Bull's trench kilns (BTK) [1]. The majority of kilns use traditional, energy intensive technologies that are highly polluting. For kilning of bricks, firewood and coal are used as fuels in all types of brick kilns [2].

The government of Nepal's "Ministry of Environment, Science and Technology (MoEST)" published the "Standard on Chimney Height and Emission for Brick Kiln Industry" on February 25, 2008 (Table 1).

Table 1. Standard on chimney height and emission for brick kiln industry.

\begin{tabular}{cccc}
\hline S.N. & Types of Kiln & $\begin{array}{c}\text { SPM (Max. limit } \\
\left.\mathrm{mg} / \mathrm{Nm}^{3}\right)\end{array}$ & $\begin{array}{c}\text { Height of chimney } \\
\text { (Min. limit, Meter) }\end{array}$ \\
\hline $\mathbf{1}$ & BTK Forced Draught (Fixed Chimney) & 600 & 17 \\
2 & BTK Natural Draught (Fixed Chimney) & 700 & 30 \\
3 & VSBK & 400 & 15 \\
\hline
\end{tabular}

Source: [17]. 


\section{Status of Environmental Pollutants in Brick Kilns (Both Environmental and Occupational)}

The traditional brick industry is a labour intensive, low technology activity which generates low income for the brick workers. The traditional brick making, as any informal industry, is highly competitive since barriers to entry are relatively low. Brick industry owners are under significant pressure to cut costs regardless of the environmental impact or minimum wages for their employee [19].

Primarily, the five types of pollution $\left(\mathrm{CO}_{\mathrm{X}}, \mathrm{NO}_{\mathrm{x}}\right.$, Hydrocarbons, Sulfur dioxide and dust) are important from the point of view of their adverse human health effects and other food chain organisms [20]. Air pollution is of special concern as it directly affects the respiratory system. Air pollution is one of the man-made environmental catastrophes that are currently taking place all over the world. The increase of pollution in the developing world is much greater as compared to its rate of increase in the developed countries [21]. Various sources of pollution include automobile exhaust, brickwork emissions, industrial factory emissions, hospital wastes, etc. Brick kilns primarily emit $\mathrm{PM}, \mathrm{CO}, \mathrm{SO}_{2}$, volatile organic compounds, nitrogen oxides $\left(\mathrm{NO}_{\mathrm{x}}\right)$, and heavy metals depending on the type of fuel burnt [22]. With the increased awareness of environmental pollution, government agencies have continuously monitored brick kiln emissions. The control of brick kiln emissions initially began with the notification of emission standards for brick kilns in April 1996.

\subsection{Gases: $\mathrm{SO}_{\mathrm{x}}, \mathrm{NO}_{\mathrm{x}}, \mathrm{CO}$ in Brick Kilns}

Traditional brick production has different impacts on the environment and human health. Brick producers use waste materials like sawdust, wood shavings, and scrap wood as fuels which contain resins and chemical compounds. Also cheaper waste materials such as old tires, used motor oil, plastics, and garbage are being used [23]. Additionally, traditional kilns have inefficient energy use because heat is not well distributed inside the kiln and lost due to bad insulation of the kiln walls. This generates higher fuel consumption and more emissions and requires more firing time [24]. Around the world, a variety of materials are used to fire brick kilns. Of the different kinds of kilns operating, some are better in terms of energy efficiency and produce less polluting emissions. The majority of kilns used in traditional brick making produce extremely large quantities of pollutants which incorporate into the air affecting abiotic and biotic elements [25]. Brick kilns are principally related to carbon monoxide and particulate emissions depending on the types of fuels used, volatile organic compounds, nitrogen oxide, sulfur dioxide, heavy metals, and carbon dioxide are also emitted [22]. Moreover, a fast increase in the burning of coal besides other biomass fuels in brick kilns results in the emissions of $\mathrm{PM}, \mathrm{BC}, \mathrm{SO}_{2}, \mathrm{NO}_{\mathrm{x}}$ and $\mathrm{CO}$ [26]. Although the principal factor of contamination in urban areas is motor vehicle traffic, it can be assumed that given the total quantity of brick kilns in developing countries, the aggregated environmental impacts can be very significant [27]. Each brick kiln fuel causes pollution, but some are worse than others. Table 2 shows some of the most commonly used fuels in brick kiln production 
Table 2. Fuel types and respective pollutant emissions.

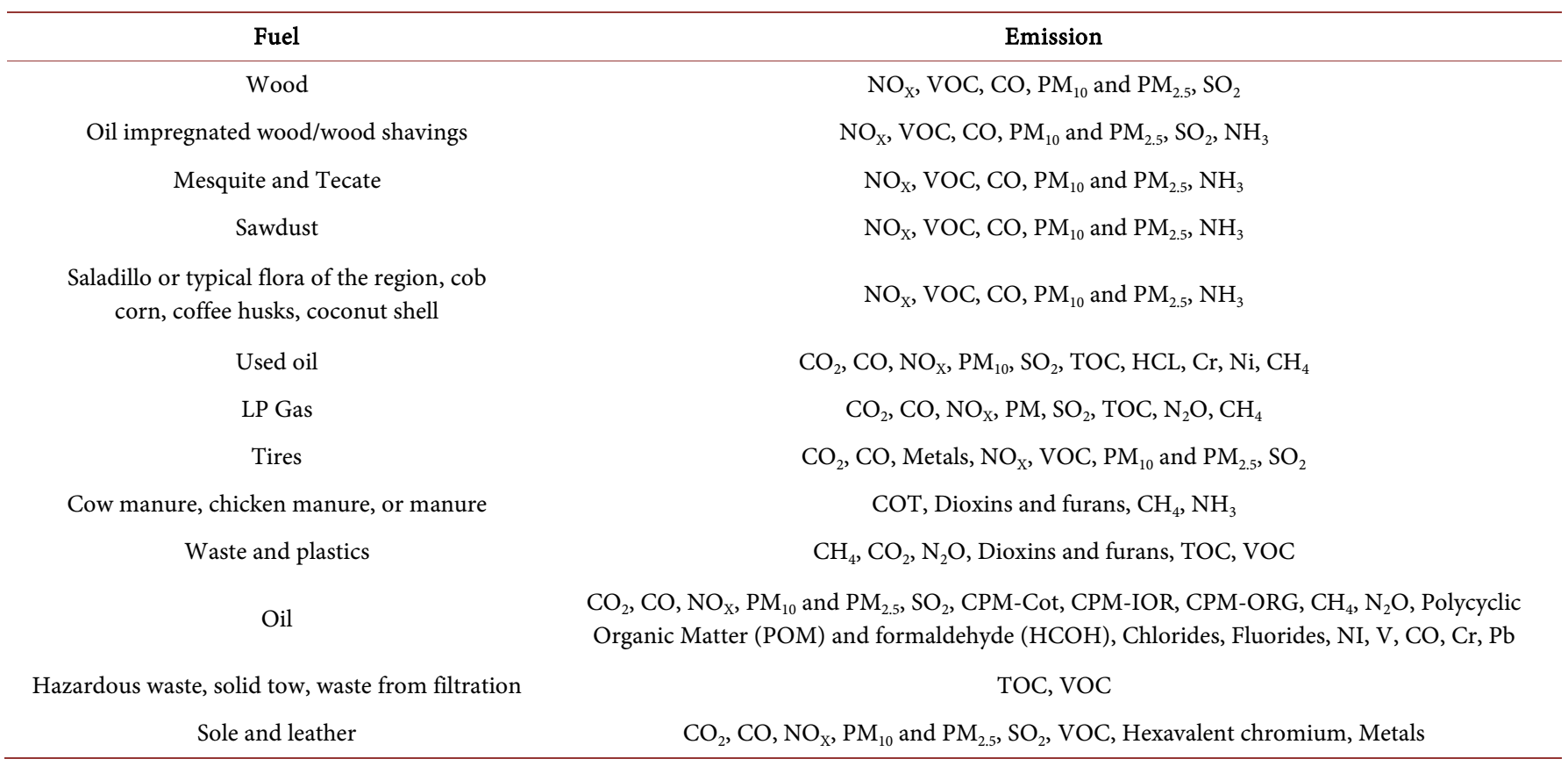

Source: [25].

and their most important pollutants.

The term $\mathrm{SO}_{\mathrm{x}}$ is a standard term which describes emissions of the oxides of sulphur, primarily $\mathrm{SO}_{2}$ and $\mathrm{SO}_{3}$ [28]. The emission of $\mathrm{SO}_{\mathrm{X}}$ in brick making has received considerable attention. Presently, $\mathrm{SO}_{2}$ is the main air pollutant in developing countries, where it contributes both to urban pollution and to regional acid rain precipitation [29]. Among man-made sources, coal burning accounts for $74 \%$, industries $22 \%$ and transportation $2 \%$ of the total $\mathrm{SO}_{\mathrm{X}}[30]$.

It is estimated that 23,300 tons of $\mathrm{PM}_{2.5}, 15,500$ tons of $\mathrm{SO}_{2}, 302,000$ tons of $\mathrm{CO}, 6000$ tons of black carbon (BC), and 1.8 million-tons of $\mathrm{CO}_{2}$ was emitted to generate 3.5 billion brick per year [22]. A brick industry producing 800,000 bricks, burns a large amounts of rubber to start the burning process and burns a total of 8 tons of low quality coal or 20 drums of used vehicle oil, thus releasing many toxic pollutants such as $\mathrm{NO}_{\mathrm{X}}$, $\mathrm{CO}$ and dioxins [31]. Both trace and non-trace gases such as $\mathrm{CO}_{2}, \mathrm{CH}_{4}, \mathrm{~N}_{2} \mathrm{O}, \mathrm{NO}_{\mathrm{x}}$ and $\mathrm{NO}$ are produced from the biomass burning. Additionally, from the biomass burning, toxic fumes containing suspended particulate matter (SPM) rich in carbon particles and high concentrations of $\mathrm{CO}$ and $\mathrm{SO}_{\mathrm{X}}$ [32]. $\mathrm{NO}_{\mathrm{X}}$ emissions in brick making is mainly derived from the oxidation of nitrogen in the atmosphere by burning biomasses [33]. Emissions of $\mathrm{NO}_{\mathrm{x}}$ also have a major role in the formation of ozone. Higher concentrations of ozone are found in the atmospheric surface stratum of rural areas. This is due primarily the brick kiln emissions [34]. Due to the improper construction of kilns, vast quantities of pollutants are emitted containing gases such as $\mathrm{CO}, \mathrm{CO}_{2}$ and $\mathrm{NO}_{\mathrm{x}}$ are discharge and hence brick kilns are acting as a route cause of the precursor gases of ozone. The presence of a little amount of $\mathrm{NO}_{\mathrm{x}}$ in the atmosphere obtains solar radiation 
and the $\mathrm{O}_{3}$ is generated [35]. A study conducted in India found that suspended particulate matter, $\mathrm{SO}_{\mathrm{X}}, \mathrm{NO}_{\mathrm{x}}$ were significantly higher in two sampling villages when compared to the control villages [36]. On average, SPM was three times more than the controls, $\mathrm{SO}_{\mathrm{X}}$ was about two times more than the controls and $\mathrm{NO}_{\mathrm{x}}$ was also almost two times more than that of the controls. The results indicated that the presence of brick industry increases the concentration of $\mathrm{SPM}, \mathrm{SO}_{\mathrm{x}}$ and $\mathrm{NO}_{\mathrm{X}}$ in the environment.

A study [18] conducted in Kathmandu valley on the specific energy consumption pattern in VSBK for firing of green bricks under ideal temperature conditions with three different internal fuel ratios viz. $40 \%, 50 \%$ and $60 \%$. They found that both consumption of coal and the level of pollutants decrease in each higher internal fueling ratios. The specific energy consumption on $60 \%$ internal fueling ratio was 0.59 mega.joules $(\mathrm{MJ}) / \mathrm{kg}$ for fired bricks. The study noted that emissions of SPM decreased with increasing internal fueling. During 60\% internal fuel ratios, respirable suspended particulate matter (RSPM) and non-respirable suspended particulate matter (NRSPM) were $8.3 \mathrm{mg} / \mathrm{m}^{3}$ and $2.9 \mathrm{mg} / \mathrm{m}^{3}$, respectively. Total dust was measured to be $11.1 \mathrm{mg} / \mathrm{m}^{3}$. Similarly, the decrease in $\mathrm{SO}_{2}$ emission with increasing internal fuel ratios was also observed in their study. However, the sulfur dioxide emission particularly depends on the nature of coal used. Moreover, the study revealed that $\mathrm{NO}_{\mathrm{x}}$ emission was only 0.154 $\mu \mathrm{g} / \mathrm{m}^{3}$ in $40 \%$ internal fuel ratio. This is not considered a serious problem because primary source of emission of $\mathrm{NO}_{\mathrm{x}}$ is gasoline which is not used in brick kiln. Similarly, carbon monoxide and $\mathrm{CO}_{2}$ emission were also less in higher internal fueling ratios than non-internal fueling ratios.

\subsection{Dust: TSP, $\mathrm{PM}_{10}, \mathrm{RSP}, \mathrm{PM}_{2.5}, \mathrm{PM}_{1}$, Silica in Brick Kiln}

The brick kiln uses coal, wood, tires and furnace oil. The coal, fuel gas and tires combustion in brick kilns produce air pollutants like $\mathrm{CO}_{\mathrm{X}}, \mathrm{SO}_{\mathrm{X}}, \mathrm{NO}_{\mathrm{X}}$ and suspended particulate matter (SPM) [21]. SPM are fine solid or liquid particles which scatter throughout the air and are produced from the burning of household and industry fuels and waste and also from natural sources such as volcanoes, dust and forest fires [37]. SPM in the chimney gases is produced by the incomplete combustion of fuel or comes from fine coal dust, ash present in coal and burnt clay particles [26]. SPM are minute airborne particles which are $<100 \mu \mathrm{m}$ [38]. The suspension of $\mathrm{PM}_{10}$ in air can last from a few minutes to many hours and can travel from $<1 \mathrm{~km}$ to $10 \mathrm{~km}$. Fine particles have an aerodynamic diameter of $<2.5 \mu \mathrm{m}\left(\mathrm{PM}_{2.5}\right)$ which are formed from gas and condensation of high temperature vapors during combustion, and are composed of $\mathrm{SO}_{\mathrm{X}}, \mathrm{NO}_{\mathrm{X}}, \mathrm{CO}$, $\mathrm{NH}_{3}$, hydrogen ion, organic compounds, metals ( $\mathrm{Pb}, \mathrm{Cd}, \mathrm{V}, \mathrm{Ni}, \mathrm{Cu}, \mathrm{Zn}, \mathrm{Mn}$, and $\mathrm{Fe}$ ), and particle bound water. The major sources of $\mathrm{PM}_{2.5}$ are fossil fuel combustion, vegetation burning, brick baking, smelting and processing of metals. Their lifetime is from days to weeks and can travel in air from 100 to $>1000 \mathrm{~km}$ [39]. SPMs are generally divided into two types: primary particles which start off directly from sources and secondary particles produced by the combination with other compounds. One example is the photo-oxidation of $\mathrm{NO}_{\mathrm{X}}$ to form nitrates [30]. PM emission in brick manufacturing 
composed of mineral matter specifically dust entrained in process, gases and condensable PMs. Condensable PMs hypothetically can include metals that have been aerosolized in the process of flaring [40].

Air pollution reduces atmospheric visibility significantly. A report published depicting the status of air pollution in Kathmandu reported that the number of days with good visibility (>8000 meters) around noon has decreased in the winter months from more than 25 days per month in the 1970s to about 5 days per month in 1992/93. Hence, PM pollution is the most significant problem in Kathmandu valley [16]. In 1992/93 TSP (Total Suspended Particle) amounted to 16,500 tons and $\mathrm{PM}_{10}$ was measured at 4700 tons. The main sources of particulate pollution are the brick industry (28\% $\mathrm{PM}_{10}$ and $31 \%$ TSP), domestic fuel combustion (25\% $\left.\mathrm{PM}_{10}, 14 \% \mathrm{TSP}\right)$, Himal cement factory $\left(17 \% \mathrm{PM}_{10}, 36 \% \mathrm{TSP}\right)$ and re-suspension of road dust (9\% $\mathrm{PM}_{10}$ and $\left.9 \% \mathrm{TSP}\right)$. However, for the $\mathrm{PM}_{10}$ concentration, which causes additional uneasiness as these particles can enter the respiratory system; the share of brick kilns was found to be above other sources (28\%). WHO air quality guidelines (AQG) for TSP and $\mathrm{PM}_{10}$ are often exceeded. There have been measured 24-hour TSP concentrations over $800 \mu \mathrm{g} / \mathrm{m}^{3}$, while the WHO AQG (for daily averages) is $150-230 \mu \mathrm{g} / \mathrm{m}^{3}$. About $50 \%$ of the population of Kathmandu is exposed to above the upper limit of WHO AQG of TSP (WHO AQG for annual average is $60-90 \mu \mathrm{g} / \mathrm{m}^{3}$ ) [41].

Studies have shown the average value of $\mathrm{PM}_{10}$ and TSP for the kiln pre-operation time was 0.029 and $0.033 \mathrm{mg} / \mathrm{m}^{3}$, respectively whereas, it was 0.050 and $0.056 \mathrm{mg} / \mathrm{m}^{3}$, respectively during the kilning periods, thus concluded that ambient air pollution due to brick kilns in the rural areas is a real problem [42]. However, the study by the Ministry of Population and Environment (MOPE) and Environmental Sector Program Support (ESPS) showed that the total suspended particulate matter has been decreasing since 2001 introducing the advance and cleaner brick firing technologies like fixed chimney, VSBK etc. and banning the operation of moving chimney [43].

There have been various studies carried out focusing on developing nations on the status of air pollution caused by brick kilns. Ismail, et al. published a report indicating elevated weight of dust with 23.8 to $46.0 \mathrm{~g} / \mathrm{m}^{2} / \mathrm{month}$ at $50 \mathrm{~m}$ away from the brick kilns. Heavy metals, such as cadmium (Cd) and chromium $(\mathrm{Cr})$ present in the dust samples are added into the environment at a rate of 0.08 and $0.52 \mathrm{~g} / \mathrm{m}^{2} / \mathrm{month}$, respectively. As a result there is a high pollution level near the brick kiln chimneys [21]. However, the $\mathrm{PM}_{10}$ and $\mathrm{PM}_{2.5}$ concentrations showed a high increase when compared with TSP concentrations in contaminated air [28]. In another study conducted near the brick industry, found that air pollutants with concentrations 411, 530.82, 1800, 82.44 gram per second $(\mathrm{g} / \mathrm{s})$ respectively for $\mathrm{NO}_{\mathrm{X}}, \mathrm{SO}_{\mathrm{X}}, \mathrm{CO}$ and $\mathrm{PM}$ at distances of $0.2,0.4,0.6,0.8,1.0$, 2, 3, 4, and $5 \mathrm{~km}$ from the source (brick kilns). When the results were compared with the National Environmental Quality Standards (NEQS) and WHO values, most of the air samples were found above WHO standards. However, samples with taken at 4 and 5 $\mathrm{kms}$ from brick plants were less than the WHO Standards [44]. Emission of individual air contaminants from brick kilns varied considerably during a kilning lot (seven days) 
and between kilns. Average emission factor values per 1000 bricks were 6.35 to $12.3 \mathrm{~kg}$ of $\mathrm{CO}, 0.52$ to $5.9 \mathrm{~kg}$ of $\mathrm{SO}_{2}$ and 0.64 to $1.4 \mathrm{~kg}$ of PM [45]. It was estimated that the annual emissions from brick kiln industry were 80 tons of PM, 30 tons of CO, 7 tons of $\mathrm{NO}_{\mathrm{X}}$ and 5 tons of $\mathrm{SO}_{\mathrm{x}}$ [46]. Currently, due to the increased cost and shortage of good quality bituminous coal, high ash, high-sulphur coal, as well as industrial wastes and loose biomass fuels are used as fuels in the brick kilns [28]. Increase in the number of brick kilns in the Kashmir valley results in the higher concentration of $\mathrm{SO}_{\mathrm{X}}, \mathrm{NO}_{\mathrm{X}}$ and PM. As in other cities of south Asia, many of the concentrations were above permissible limits [1] [47].

In addition to the common air pollutants such as TSP, $\mathrm{NO}_{\mathrm{x}}$ or $\mathrm{SO}_{\mathrm{X}}$, brick kilns also produce a variety other environmental pollutants like silica, radon or radiation depending on the type of fuel used. However, studies tracing non-common pollutants are scarce. Nonetheless, such studies have been carried out extensively in other industrial sectors. In one study carried out among ceramic workers in Egypt found that quartz to be greater than $5 \%$ and radon greater than $4 \rho \mathrm{ci} / \mathrm{L}$. This has led to the increase in respiratory illnesses among workers in this industry [48].

\subsection{Heat Stress in Brick Kilns}

The term occupational stress, associated with the person's job, may include physical, social, drug, fatigue or cyclical stressor. Physical stressors mostly include environmental stressors like internal and external heat, cold, light, darkness, noise and vibration. Individual response to such exposure varies according to the protective measures followed [49]. But, in most of developing countries there is hardly any scope for protective work culture in unorganized sector such as brick kilns. Human body performance is extremely limited when exposed to heat. Heat stress is a recurring problem in many industries including smelting, mining, laundries, kitchens, bakeries, electrical utilities (particularly boiler rooms), foundries, brick kilning and ceramic operations [50]. Individual differences in heat tolerance levels, the type of work, clothing worn, air circulation, and other variables preclude the establishment of absolute limits for tolerance of heat that differentiate "safe" and "unsafe" levels. In the brick kiln industry the molding and firing of bricks is a significant work. The firing work in brick kiln industry is team work for 24 hours with a work-rest cycle. The temperature of the kilns is about $900^{\circ} \mathrm{C}$ to $1200^{\circ} \mathrm{C}[26]$.

Excessive exposure to hot environments result in a variety of heat-related disorders such as heat stroke, heat exhaustion, dehydration, heat syncope, heat cramps, and heat rash. Heat stress potentially increases the risks of injuries in the workplace. Due to heat stress workers fatigue sooner leading to carelessness. Concentrating on work performance and safety becomes difficult and can lead to workers not focusing on safety protocols [51].

The American Conference of Governmental Industrial Hygienists (ACGIH) and the National Institute for Occupational Safety and Health (NIOSH) set voluntary guidelines to protect workers from heat stress. Core body temperatures more than $380 \mathrm{C}$ is a 
indication that one is experiencing heat stress [52].

Rastogi, et al. [53] studied body responses prevalence of heat-related illnesses among 35 workers in brick kiln plants. Internal kiln temperatures ranged between $900^{\circ} \mathrm{C}$ to $1100^{\circ} \mathrm{C}$. These workers were continuously exposed to high thermal radiation for 8 to 10 hours a day. Responses such as heart rate showed that workers had insufficient recovery periods during rest potentially leading to cardiovascular stress among the workers. Increased cardiac workload under the existing hot conditions near the brick kilns added to the cardiovascular stress in these workers. Similarly, heat-induced hyperventilation syndrome contributed chiefly by increased respiratory frequency (Rf) and tidal volume (Vt) lead to respiratory stress caused by occupational heat stress. The increased sweating rate (623.6 plus minus $105.4 \mathrm{~g} / \mathrm{h}$ ) and sweat loss (1137.4 plus minus $238.6 \mathrm{ml}$ ) contributed to body dehydration of more than $2 \%$ among the heat-exposed workers. The chief heat-related illnesses found among the workers were headache (34.3\%), insomnia (25.7\%), heat cramps $(20 \%)$ and skin rashes (14.2\%). However, none of the heat-exposed workers exhibited signs and symptoms of heat stroke during and after heat exposure in the brick kiln industry. Similarly, consequences of heat stress on female brickfield workers included a linear decline in productivity as the air temperature reached $34.90 \mathrm{C}$ and higher. The cardiac values [peak heart rate (HRp), net cardiac cost (NCC), relative cardiac cost (RCC), and recovery heart rates] were significantly higher on hotter days (Wet Bulb Globe Temperature (WBGTout) index: $26.9^{\circ} \mathrm{C}$ to $30.74^{\circ} \mathrm{C}$ ) than on cooler days (WBGTout index: $16.12^{\circ} \mathrm{C}$ to $19.37^{\circ} \mathrm{C}$ ) for the brick molders; however, this was not the case for the brick carriers [54]. A coping strategy employed by the brick carriers was to reduce their walking speed and thus lose part of their earnings. The lost productivity for every degree rise in temperature is almost two percent in the brick workers [53].

\subsection{Ergonomic Factors in Brick Kilns}

Studies in brick kilns indicated that this type of exhausting work may result in upper limb disorders. An investigation of musculoskeletal disorders (MSDs) in a manually operating brick company focused on the area where clay is shaped into bricks [55]. When posture and force were analyzed it was found that poor standing posture and undesirable wrist positions, accompanied by significant force loadings were the risk factors. The study identified that an important contributory factor for MSD is the piecework system. Likewise, it was observed that the workers adapted to squatting postures while making bricks, carried loads in excess of recommended loads weighing $12-40 \mathrm{~kg}$. This resulted in many workers $(81 \%)$ claiming pain in different parts of body including the low back (50\%), neck (38\%) and shoulder (29\%) [56].

\section{Health Status of Brick Kiln Workers}

\subsection{Illnesses in Brick Kiln Workers}

Introduction of potentially harmful substances like gases and particulate matter from modern industrial civilization is recognized as having a tremendous negative and 
harmful impact on living organisms. These pollutants in the atmosphere exist in solid, liquid and gaseous states and interfere with the legitimate use of the air by the organisms creating various problems for them [1]. Among the various categories of workers on brick industries, the fire masters, brick unloaders and workers who handle ash have the highest level of contact to the pollutants. When workers inhaled these pollutants, the result was irritation of skin and eyes and potentially resulted in respiratory diseases such as pneumoconiosis and silicosis, which are caused by inhaling siliceous dust [26]. Hence, workers in brick industries are prone to respiratory diseases such as silicosis, pneumonocosis and MSDs [36]. Another study identified that there are multiple risk factors and the health problems are directly related with biomechanical, psychosocial, nutritional, clinical and respiratory ailments [57].

In Spain, it is reported that some brick kilns emitted fluoride, chlorine, and bromine in addition to other toxic gases [58]. A health survey clearly showed that people living around brick kilns are more likely to suffer from illnesses caused by kilns' pollution, comparing those who are living in areas without the brick factories. School children near to the brick companies had the worst health status and suffered upper respiratory infections like pharyngitis and tonsillitis [42] [59].

The association between respiratory health effects and brick kiln pollution is validated by several studies. Spirometric measurement among workers in five old fashion brick factories located in Najaf Province, Iraq showed that workers of the five brick factories scored lower values of the four spirometric variables than the control subjects. Significant differences were also found among workers with different job tenure with the workers group of 11 - 15 years of employment scoring the lowest values. Their result concluded that brick industry workers are at risk of developing obstructive respiratory impairment and/or restrictive respiratory impairment and the extent of this ailment directly correlates with the duration of work [60].

\subsection{Injuries in Brick Kiln Workers}

Brick production is a labor demanding industry requiring muscular energy at most of its production stages. Workers are required to carry heavy loads, remain in squatted postures for long periods and do highly repetitive tasks. Work-related musculoskeletal disorders (WMSD) are common in workers in brick production enterprises. Hazards in the brick kilns cause human injuries and cause economic cost by decreasing working capacity [51]. It is evident that prolonged sitting in squatted postures causes numbness in the lower legs resulting from lack of blood supply due to sustained muscle compression, which in turn leads to MSDs [57]. Moreover, the processes in brick kilns involve the interactions of various personal factors including fitness, age, and experience of the workers [61].

A cross sectional study of children aged 17 years and under in Bhaktapur and Sarlahai districts of Nepal identified that work-related physical ailments and discomforts dominated the brick industries of Nepal. Among brick worker children, pain and discomfort was experienced by $73 \%$ and $58 \%$ of working children, respectively in Bhakta- 
pur and Sarlahi. The odds ratio suggests that working children were eight times more likely to experience trouble or body pain compared to non-working children. This study finds that the low quality physical environment, working conditions and practices in brick industries has contributed to musculoskeletal injuries and chronic health ailments [62].

The work-related backgrounds, the effect of physiological, biomechanical, musculoskeletal and psychosocial discomforts prevalence, was examined among workers in brick kilns of West Bengal, India. Biomechanical analysis pointed out that the workers are continuously adapting awkward postures, such as squatting, bending and lifting of loads resulting in severe back pain and constant aches in the hands feet. In terms of nutritional status, most of the women were emaciated and malnourished [57].

Children are the risk group to suffer more from various levels of health impacts due to severe working conditions such as brick kilns. An ILO study identified associated risk involved in children as heat stress, joint and bone deformities, musculoskeletal problems from repetitive motion, blistered hands, bruised feet from dropped bricks, lacerations, breathing difficulties, silicosis and other occupational lung diseases, insect bites, malnutrition, bacterial and viral diseases, and injury from moving vehicles as the major health impacts from the brick industry [63].

\subsection{Reproductive Health Problems Brick Kiln Workers}

Low birth weight, preterm birth and gestational problem have a substantial public health impact [64] and there are evidences which have validated association between air pollutants and reproductive health problems, however, there are few studies specifically dealing on the subject in brick kiln industries. A study carried out in in India compared two groups of female workers; one working in the brick kilns (experimental group) and another in agriculture (control group). The study found blood pressure, serum progesterone and progesterone/estrogen ratio much lower in the brick kiln female workers compared to their counterpart showing normal values. However, individual estrogen status \& follicle stimulating hormone status was found to be much higher in workers than their respective clinical values. Specific workstation-related ergonomic parameters indicated the awkward postures are linked to their work types. These ergonomic risk factors needed immediate remedial measure to prevent the early emergence of PMS

(pre-menopausal syndrome) amongst these workers [49]. Similarly, gynecological complaints amongst (56\%) of female subjects while making bricks were also noted [56].

\subsection{Gastro-Intestinal Health Problems in Brick Kiln Workers}

Working in sub-standard working environments and combination of stress and negative emotions contribute to gastrointestinal tract (GIT) alterations. In particular, jobs that create deprivation, fatigue, chronic mental anxiety and a long history of tension, frustration, resentment, psychological disturbance or emotional conflict have been shown to produce gastric ulcers [65].

It is extremely difficult to differentiate causative factor for health issues, such as ga- 
stro-intestinal problems from those which derive from the living conditions and other poverty-related factors characteristic of brick kiln families [63]. Nonetheless, quite a few studies have identified a higher prevalence of gastrointestinal problems as to brick workers than control subjects. A study conducted on 2545 brick kiln workers around Ahmedabad, India found that $12.7 \%$ suffered from problems related with digestive system [66].

Similarly, an observational study in factories following FCBTK and VSBK brick production technologies specified that the fraction of workers complaining about health problems were higher in FCBTK. Among workers with health problems, gastrointestinal tract, skin-related illnesses, respiratory complaints and genitourinary tract problems were more prevalent for FCBTK workers than for VSBK workers. Furthermore, research conducted in Brisbane, Australia also demonstrated the significant association between ambient air pollutants such as particles, ozone, sulfur dioxide, and nitrogen dioxide on daily admissions in hospital for asthma and respiratory diseases, cardiovascular ailments, along with digestive disorders [67] [68].

\subsection{Mental Illnesses in Brick Kiln Workers}

In 2001, the ILO published the ILO-OSH 2001 document entitled "Guidelines on Occupational Safety and Health Management Systems" to assist organizations introducing OSH management systems [69]. Generally, OSH hazards are considered as physical, chemical, biological and/or ergonomic factors. It is rare to find psychological factors, such as stress, mentioned as a OSH problem [65].

\section{Constitutional Provision on OHS in Nepal}

The constitution of Nepal, 2015 enshrines several provisions concerning occupational safety and health. It has prioritized the human rights and protection of environment. The freedom to access health services, live in clean and healthy environment (Article 30), undertake a profession, job including business or trading concern lies within the framework of fundamental human rights. These include the banning of slavery and forced labor; freedom of assembly, association and speech; freedom of trade, business, and profession; right of equality, promotion of social security and economic well-being of the people, and eradication of the social evils. Article 42 stated that, citizens who are economically very poor shall have the right to special opportunity and facilities in the areas of education, health, housing, employment, food and social security, for their protection, progress, empowerment and development.

Moreover, the constitution entrusts that the state shall incorporate policies that guarantee the elementary needs of citizens. One example of an elementary need is to ensure easy and accessible access for all to quality health service. In addition, the constitution mandates that state's policies related to labor and employment shall promote employment in Nepal by ensuring conditions to work for all and developing a capable and professional manpower, guaranteeing social security by ensuring basic rights of all workers and laborers based on the concept of dignity of labor, ending all forms of ex- 
ploitation of labor including exploitation of child labor, ensuring the participation of workers or laborers in management, regulating and managing the foreign employment sector to make it exploitation free, safe and systematic and guarantee the employment and rights of the workers or laborers, motivating the capital, skills, technology and experience earned through foreign employment to be utilized in productive sectors in Nepal.

\section{National Labor Policy on OSH}

The critical challenge in Nepal is enhancing the quality of jobs for all, including youth, women and marginalized groups. The vast majority of Nepal's workforces are engaged in unproductive and poorly remunerated jobs, typically in the informal economy, without legal or social protection and often without representation or a voice in the workplace. Such work often entraps Nepalese in a cycle of working poverty. Increasing the quality of jobs will require as a starting point an enabling environment, including rule of law, secure property rights and respect for fundamental principles and rights at work [70]. Similarly, improvements in workplace conditions, including occupational safety and health standards, are also important to productivity. Locally-available and low-cost solutions such as good housekeeping, good lighting, improved workstations for better work posture, machine guards, safer handling of hazardous substances and basic welfare needs such as safe drinking water and sanitary toilets can play an important role in enhancing the productivity of workers [11] [71].

Perceiving the need for a distinct policy for the labor sector and to mainstream the work related issues, the government of Nepal has formulated and enforced the "National Labor Policy 1999". In the objectives of the National Labor Policy, it has been stated that Labor Standards determined by the International Labor Organization with respect to the health, social security and welfare of labor would be implemented according to the situation of the country. As to the policy, it is mentioned that occupational health and safety provisions be developed and made stronger in the enterprises [72]. The enforcement of the policy has made it possible for the Nepalese labor sector to take on a concrete shape and for the efforts for organizing and streamlining the labor sector to proceed along the International Labor Organization's (ILO) basic guidelines. However, the policy could not address the ever-changing cross-cutting agendas of labor and employment sectors. For example, Nepal became a member of World Trade Organization (WTO) in 2004 and incorporation of newer provisions were imminent. In that context, updated Labor and Employment Policy 2062 has been promulgated in response to the need for incorporation of emerging issues ("Labour and Employment policy of Nepal" 2005). The policy envisioned making the labor market safe, healthy, competitive and open by developing a social security system that also encompasses the informal sector, as well as by promoting and developing occupational safety and health.

\section{Conclusion}

Brick manufacturing is a highly pollution prone work place. It encompasses both health 
and economic burdens demanding thriving integration of brick production and marketing tasks with the socio-economic excellence of life of the citizens. It should be matching with a two branched strategy i.e. technical and social aspects in its interventions [73]. Brick kiln workers face various health problems for mainly respiratory, musculoskeletal, gastrointestinal, injuries, reproductive and mental health. To mitigate the respiratory health problems, the policies on improvement of less pollutants production technologies, for example exploitation of Hoffman or VSBK technology, have to be prepared and implemented. The policies on the use of protective devices for example use of gloves, boots, goggles and respirators, should be mandatory from both owners and workers [73]. Similarly, to combat musculoskeletal problems, the policies on ergonomics should be developed and implemented. For the prevention of injuries, uses of protective devices and technology have to be encouraged. Additionally, the policies on this have to be developed and implemented. Reproductive health problems are the hidden concern for brick kiln workers, especially for the women workers. Reproductive health friendly working environment should be backed by the policies [5]. Gastrointestinal health problem is one of the major concerns for the brick kiln workers because there is no sufficient and clean water supply including use of toilets. The policies must be focused to supply sufficient quantity of clean water and construction and use of toilets. Mental health is a great concern for brick kiln workers because it is very low paid job and has to work under pressure in an excessively polluted worksite.

\section{References}

[1] Fatima, I. (2011) Impact of Brick Kiln Emissions on the Ambient Air Quality and Vegetation: A Case Study of District Budgam. Ph.D. Thesis, Srinagar-190006, The University of Kashmir, India.

[2] GEFONT (2007) Nepal: Labour Under the Chimney-A Study on the Brick Kilns of Nepal. Putalisadak, Kathmandu, Nepal: General Federation of Nepalese Trade Unions (GEFONT), Man Mohan Labour Building, GEFONT Plaza.

[3] Maskey Manandhar, U. and Dangol, S.B. (2013) Study on Evaluating Energy Conservation Potential of Brick Production in SAARC Countries. A Report on Nepal, MinErgy Nepal.

[4] Raut, A.K. (2003) Brick Kilns in Kathmandu Valley: Current status, environmental impacts and future options. Him J Sciences, 1, 59-61.

[5] Figà-Talamanca, I. (2006) Occupational Risk Factors and Reproductive Health of Women. Occupational Medicine, 56, 521-531. https://doi.org/10.1093/occmed/kql114

[6] Hollander, D. (1997) Environmental Effects on Reproductive Health: The Endocrine Disruption Hypothesis. Family Planning Perspectives, 29, 82-89. https://doi.org/10.2307/2953367

[7] Kaushik, R., Khaliq, F., Subramaneyaan, M. and Ahmed, R. (2012) Pulmonary Dysfunctions, Oxidative Stress and DNA damage in Brick Kiln Workers. Human \& Experimental Toxicology, 31, 1083-1091. https://doi.org/10.1177/0960327112450899

[8] Manoharan, P.K., Singh, B.K. and Jha, S.K. (2012) Ergonomics Investigation Using Psycho-Physiological Study for Brick Kilns' in Jharkhand. International Journal of Environmental Sciences, 2, 1484-1491.

[9] Ray Chaudhuri, S.S., Biswas, C. and Roy, K. (2012) A Subjective and Objective Analysis of 
Pain in Female Brick Kiln Workers of West Bengal, India. International Journal of Occupational Safety and Health, 2, 38-43. https://doi.org/10.3126/ijosh.v2i2.6597

[10] Shaikh, S., Nafees, A.A., Khetpal, V., Jamali, A.A., Arain, A.M. and Yousuf, A. (2012) Respiratory Symptoms and Illnesses among Brick Kiln Workers: A Cross Sectional Study from Rural Districts of Pakistan. BMC Public Health, 12, 999,

http://www.biomedcentral.com/1471-2458/12/999

https://doi.org/10.1186/1471-2458-12-999

[11] Joshi, S.K. and Dahal, P. (2009) Occupational Health Services in Nepal. Asian Pacific Newsletter on Occupational Health and Safety, 16, 30-32.

[12] Joshi, S.K., Shrestha, S. and Vaidya, S. (2011) Occupational Safety and Health Studies in Nepal. International Journal of Occupational Safety and Health, 1, 19-26. https://doi.org/10.3126/ijosh.v1i1.4725

[13] Alli, B. (2008) Fundamental Principles of Occupational Health and Safety [English]. International Labour Organization, Geneva.

[14] Gautam, R.P. and Prasain, J.N. (2011) Current Situation of Occupational Safety and Health in Nepal. General Federation of Nepalese Trade Unions (GEFONT) Man Mohan Labour Building, GEFONT Plaza, Putalisadak, Kathmandu, Nepal.

[15] Joshi, S.K. (2011) Occupational Safety and Health in Nepal. International Journal of Occupational Safety and Health, 1, 1-2. https://doi.org/10.3126/ijosh.v1i1.5224

[16] URBAIR (1996) Kathmandu Report. Kathmandu.

[17] MoEST (2010) Environmental Pollution Control and Monitoring Section, Environment Division, Ministry of Environment Science \& Technology, Singhdurbar. A Brief Note, Kathmandu, 7.

[18] Adhikari, S., Dangol, S.B. and Byanju, R.M. (2013) Use of Charcoal as Internal Fuel in Vertical Shaft Brick Kiln. Rentech Symposium Compendium, 3, 22-25.

[19] Croitoru, L. and Sarraf, M. (2012) Benefits and Costs of the Informal Sector: The Case of Brick Kilns in Bangladesh. Journal of Environmental Protection, 3, 476-484. https://doi.org/10.4236/jep.2012.36058

[20] Khattak, J.K. and Parveen, S. (1999) Co-Operative Research Programme on Micronutrients in Pakistan. Annual Report (1988-99), Peshawar.

[21] Ismail, M., Muhammad, D., Khan, F.U., Munsif, F., Ahmad, T., Ali, S., et al. (2012) Effect of Brick Kilns Emissions on Heavy Metal (Cd and Cr) Content of Contiguous Soil and Plants. Sarhad Journal of Agriculture, 28, 165-170.

[22] Guttikunda, S.K., Begum, B.A. and Wadud, Z. (2012) Particulate Pollution from Brick Kiln Clusters in the Greater Dhaka Region, Bangladesh. Air Quality, Atmosphere \& Health, 6, 357-365. https://doi.org/10.1007/s11869-012-0187-2

[23] Huston (2002) A Study of Brick-Making Processess along the Texax Portion of the USMexico Border. Austin.

[24] Maithel, S. and Uma, R. (2012) Brick Kilns Performance Assessment. GREENTECH, Enzen, Cleanair Taskforce, New Delhi.

[25] Erbe, S.O. (2012) Technical, Economical and Organizational Analysis of Informal Brick Production in Tercera Chica, SLP, Mexico. Cologne University of Applied Science, San Luis Potosi.

[26] Maithel, S., Vasudevan, N., Johri, R. and Kumar, A. (2002) Pollution Reduction and Waste Minimization in Brick Making Habitat Place. Tata Research Institute, Lodhi Road, New Delhi. 
[27] Heierli, U. and Maithel, S. (2008) Brick by Brick: The Herculean Task of Cleaning up the Asian Brick Industry. New Delhi.

[28] Skinder, B.M., Sheikh, A.Q., Pandit, A.K. and Ganai, B.A. (2014) Brick Kiln Emissions and Its Environmental Inpact: A Review. Journal of Ecology and the Natural Environment, 6, 1-11. https://doi.org/10.5897/JENE2013.0423

[29] Cofala, J., Amann, M., Gyarfas, F., Schoepp, W., Boudri, J.C., Hordijk, L., et al. (2004) Cost-Effective Control of $\mathrm{SO}_{2}$ Emission in Asia. Journal of Environment Management, 72, 149-161. https://doi.org/10.1016/j.jenvman.2004.04.009

[30] De, A.K. (2012) Environmental Chemistry. 7th Edition, New Age International Pvt Limited, New Delhi.

[31] EPA (2007) Air Pollution in Peshawar. NWFP-Pakistan, Peshawar.

[32] Alam, S.A. (2006) Use of Biomass Fuels in the Brickmaking Industries of Sudan: Implicatins for Deforestation and Greenhouse Gas Emission. MSc Thesis, University of Helensiki, Helensinki.

[33] Pauls, N. (1989) Survey of the Emission of Pollutants in Brick and Tile Production.

[34] Elampari, K., Chithambarathanu, T. and Sharma, R.K. (2010) Examining the Variations of Ground Level Ozone and Nitrogen Dioxide in a Rural Area Influenced by Brick Kiln Industries. Indian Journal of Science and Technology, 3, 900-903.

[35] Tang, L. (2009) Regional and Local Surface Ozone Variations in Relatin to Meteorological Conditions in Sweden. PhD Thesis, Department of Earth Science, University of Gothenburg, Gothenburg.

[36] Khan, R. and Vyas, H. (2008) A Study of Impact of Brick Industries on Environment and Human Health in Ujjain City (India). Journal of Environmental Research and Development, 2, 421-425.

[37] Emberson, L.D., Ashmore, M.R., Murray, F., Kuylenstierna, J.C.I., Percy, K.E., Izuta, T, et al. (2001) Impacts of Air Pollutants on Vegetaion in Developing Countries. Water Air and Soil Pollution, 130, 107-118. https://doi.org/10.1023/A:1012251503358

[38] EPA (2012) What Are the Six Common Air Pollutants? Air Pollution.

[39] Reddy, Y.B.R., Reddy, S.M. and Reddy, C.B.S. (2015) Determination of Respirable Suspended Particulate Matter, Non Respirable Suspended Particulate Matter and Total Suspended Particulate Matter in Piduguralla Industrial Area India. International Research Journal of Environmental Science, 4, 45-51.

[40] Brosnan, D.A. (2000) Ceramic and Brick Manufacturing. In: Davis, W.R., Ed., Air Pollution Engineering Manual, John Wiley and Sons, New York, 681-690.

[41] Adhikari, J. and Bohle, H.G. (1999) Urbanization, Government Policies and Growing Food Insecurity in Kathmandu Metropolis. Studies in Nepali History and Society, 4, 191-246.

[42] Joshi, S.K. and Dudani, I. (2008) Environmental Health Effects of Brick Kilns in Kathmandu Valley. Kathmandu University Medical Journal, 6, 3-11.

[43] ADB (2004) Country Environment Analysis. Kathmandu.

[44] Hassan, M., Mumtaz, W., Raza, I., Adil Syed, W.A. and Ali, S.S. (2012) Application of Air Dispersion Model for the Estimation of Air Pollutants from Coal-Fired Brick-Kilns Samples in Gujrat. Science International, 24, 41-45.

[45] Lee, H.A. and Oanh, N.T.K. (2010) Integrated Assessment of Brick Kiln Emission Impacts on Air Quality. Environment Monitoring Assessment, 171, 381-394. https://doi.org/10.1007/s10661-009-1285-y

[46] Asgher, M.S., and Singh, A.L. (2003) Land Degradation through Brick Kiln: A Case Study of 
Aligarh, India. Indian Journal of Regional Science, 35, 77-84.

[47] Hussan, A., Bhat, G.A. and Sheikh, M.A. (2013) Impact of Brick Kiln and Vehicular Emissions on Lichen Diversity in Khanabal Area of Anantnag District (J\&K), India. International Research Journal of Environmental Sciences, 2, 30-33.

[48] Aziz, H.M., Ahmed, S.B. and Saleh, I.A. (2010) Respiratory Hazards among Egyptian Ceramics Workers. Researcher, 2, 65-73.

[49] Bagchi, A., Das, S., Karmakar, S. and Ghosh, S. (2014) Occupational and Ergonomic Health Analyses of Female Construction Workers of West Bengal, India. Journal of Analytical Pharmacology and Biological Sciences, 3, 55-62.

[50] Chaudhary, R., Ajit, V.M. and Srivastava, R.K. (2012) Reduction of Occupational Health Hazards of Firer in Brick Kiln Industry Using Artificial Neural Network and Genetic Algorithm. International Journal of Computer Science and Communication Engineering.

[51] Chaudhary, S.S.R., Biswas, C. and Roy, K. (2012) A Subjective and Objective Analysis of Pain in Female Brick Kiln Workers of West Bengal, India. International Journal of Occupational Safety and Health, 2, 38-43.

[52] ACGIH (2004) Threshold Limit Values for Chemical Substances and Physical Agents and Biological Indices. Cincinnati.

[53] Rastogi, S.K. (2002) Enironmental Factors and Physiological Strain in Workers Employed in Brick Kilns. Indian Journal of Occupational and Environmental Medicine, 6, 66-70.

[54] Sett, M. and Sahu, S. (2014) Effects of Occupational Heat Exposure on Female Brick Workers in West Bengal, India. Global Health Action, 7, 21923.

https://doi.org/10.3402/gha.v7.21923

[55] Trevelyan, F.C. and Haslam, R.A. (2001) Musculoskeletal Disorders in a Handmade Brick Manufacturing Plant. International Journal of Industrial Ergonomics, 27, 43-55. https://doi.org/10.1016/S0169-8141(00)00036-6

[56] Basu, K., Sahu, S. and Pauls, G. (2008) Women and Work. Asian-Pacific Newsletter on Occupational Health and Safety. Finnish Institute of Occupational Health Topeliuksenkatu 41 a A FI-00250, Helsinki.

[57] Bandyopadhyay, B. and Sen, D. (2014) Occupational Stress among Women Molders: A Study in Manual Brick Manufacturing Industry of West Bangel. International Journal of Scientific and Research Publications, 4, 1-7.

[58] Gonzalez, I., Galan, E. and Fabbri, Y. (2002) Estimation of Fluorine and Chlorine Emissions from Spanish Structural Cermic Industries: The Case Study of the Baillen Area, Southern Spain. Journal of Atmospheric Environment, 36, 5289-5298. https://doi.org/10.1016/S1352-2310(02)00645-3

[59] Pariyar, S.K., Das, T. and Ferdous, T. (2013) Environment and Health Impact for Brick Kilns in Kathmandu Valley. International Journal of Scientific \& Technology Research, 2, 184-187.

[60] Al-Shamma, Y.M.H., Dinana, F.M. and Dosh, B.A. (2009) Physiological Study of the Effect of Employment in Old Brick Factories on the Lung Function of Their Employees. Journal of Environmental Studies, 1, 39-46.

[61] Qutubuddin, S.M., Hebbal, S.S. and Kuma, A.C.S. (2013) Ergonomic Evaluation of Tasks Performed by Workers in Manual Brick Kilns in Karnataka, India. Global Journal of Research in Engineering, 13, 35-42.

https://globaljournals.org/GJRE_Volume13/4-Ergonomic-Evaluation-of-Tasks-Performed. pdf 
[62] Joshi, S.K., Dahal, P., Poudel, A. and Sherpa, H. (2013) Work Related Injuries and Musculoskeletal Disorders among Child Workers in the Brick Kilns of Nepal. International Journal of Occupational Safety and Health, 3, 2-7.

[63] ILO (2011) Children in Hazardous Work: What We Know, What We Need To Do?

[64] Stieb, D.M., Chen, L., Eshoul, M. and Judek, S. (2012) Ambient Air Pollution, Birth Weight and Preterm Birth: A Systematic Review and Meta-Analysis. Environmental Research, 117, 100-111. https://doi.org/10.1016/j.envres.2012.05.007

[65] Huerta-Franco, M.R., Vargas-Luna, M., Tienda, P., Delgadilo-Holtfort, I., Balleza-Ordaz, M. and Flores-Hernandez, C. (2013) Effects of Occupational Stress on the Gastrointestinal Tract. World Journal of Gastrointestinal Pathophysiology, 4, 108-118. https://doi.org/10.4291/wjgp.v4.i4.108 https://scholar.google.com/scholar?q=Effects+of+occupational+stress+on+the+gastrointest inal+tract. $+\& b \operatorname{tnG}=\& h \mathrm{hl}=$ en\&as_sdt $=0 \% 2 \mathrm{C} 5$

[66] Mehta, R., Pandit, N. and Parmar, R. (2010) Morbidity Profile of Brick Kiln Workers around Ahmedabad City, Gujarat. Healthline, 1, 41-44.

[67] Petroeschevsky, A., Simpson, R.W., Thalib, L. and Rutherford, S. (1996) Associations between Outdoor Air Pollution and Hospital Admissions in Brisbane, Australia. Epidemiology Community Health, 50, 36-41.

[68] Murthy, V.K., Khanal, S.N. and Giri, D. (2007) Occupational Health and Safety Study (OHSS) of Brick Industry in the Kathmandu Valley Report. A Report, Kathmandu University, Dhulikhel, Kavre.

[69] ILO (2001) Guidelines on Occupational Safety and Health Management Systems. Geneva.

[70] ILO (2010) Labour and Social Trends in Nepal. Kathmandu.

[71] Joshi, S.K. (2013) Occupational Health and Safety Assessment of Child Workers in the Brick Industry, Nepal. World Education \& Kathmandu Medical College, Kathmandu.

[72] Vaidya, S.N. (2003) Occupational Safety and Health Situation in Nepal. Kathmandu.

[73] DMC-Nepal (2013) Situatinal Analysis of Workers in Some Brick Industries around Kathmandu Valley. Kathmandu. for you:

Accepting pre-submission inquiries through Email, Facebook, LinkedIn, Twitter, etc. A wide selection of journals (inclusive of 9 subjects, more than 200 journals)

Providing 24-hour high-quality service

User-friendly online submission system

Fair and swift peer-review system

Efficient typesetting and proofreading procedure

Display of the result of downloads and visits, as well as the number of cited articles

Maximum dissemination of your research work

Submit your manuscript at: http://papersubmission.scirp.org/

Or contact ojsst@scirp.org 